\title{
The Red-fin Goby, Evorthodus minutus Meek \& Hildebrand, 1928: a new record from Santa Cruz Island, Galapagos Archipelago
}

\author{
Omar Valencia-Méndez ${ }^{1}$, Dave Catania² Andrés López-Pérez $^{3}$ \\ 1 Doctorado en Ciencias Biológicas y de la Salud, Universidad Autónoma Metropolitana, San Rafael Atlixco \#186, Vicentina, 09340 Ciudad de \\ México, México. 2 Department of Ichthyology, California Academy of Sciences, 55 Music Concourse Drive, 94118 San Francisco, California, USA. \\ 3 Departamento de Hidrobiología, Universidad Autónoma Metropolitana, San Rafael Atlixco \#186, Vicentina, 09340 Ciudad de México, México. \\ Corresponding author: Andrés López-Pérez; alopez@xanum.uam.mx
}

\begin{abstract}
The Red-fin Goby, Evorthodus minutus Meek \& Hildebrand, 1928, is a coastal brackish species which is commonly distributed from Sinaloa, Mexico to Guayaquil, Ecuador and particularly abundant in mangroves of Central American eastern Pacific. We report a new record of E. minutus collected from the Santa Cruz Island, part of the Galapagos Archipelago. This new record represents a range extension and is allows for a relevant discussion about colonization pathways in the equatorial eastern Pacific of a brackish-water species.
\end{abstract}

\section{Key words}

Biodiversity, brackish gobies, fish collections, oceanic island, Tropical Eastern Pacific.

Academic editor: Hudson Tercio Pinheiro | Received 12 October 2018 | Accepted 13 December 2018 | Published 4 January 2019

Citation: Valencia-Méndez O, Catania D, López-Pérez A (2018) The Red-fin Goby, Evorthodus minutus Meek \& Hildebrand, 1928: a new record from Santa Cruz Island, Galapagos Archipelago. Check List 15 (1): 1-5. https://doi.org/15.1.1

\section{Introduction}

The family Gobiidae is the largest marine fish family with nearly 1,880 species around the world (Fricke et al. 2018). To date, gobies from Tropical Eastern Pacific (TEP) encompass 87 described species that inhabit marine, brackish and freshwater environments of the coastal zone and oceanic islands (Valencia-Méndez et al. 2018) and from shallow to depths that include the twilight zone (e.g. Bussing 1990, 1997). Despite the family's high diversity in the TEP, the group remains poorly studied there, and Valencia-Mendez et al. (2018) noted the existence of large unprospected areas and habitats where additional systematic surveys may still render complete biological inventories.

The genus Evorthodus was first diagnosed by Gill (1859), and later by Ginsburg (1931) and Dawson (1967).
According to Pezold (2004) and Cheffe et al. (2010), the synapomorphy that defines the genus are head short, snout profile steeply rounded with 2 pores between eyes, short mouth overhung by snout, and the presence of incisiform teeth in juveniles and females. Evorthodus is an American genus, which is included within the tribe Gobiosomatini, a diverse clade that comprises more than 130 species and 27 genera in the western Atlantic and eastern Pacific oceans. They are often referred to as the "American seven-spined gobies". The genus Evorthodus contains 2 species, Evorthodus lyricus (Girard, 1858) from western Atlantic and Greater Caribbean, and E. minutus from the TEP. Based on detailed morphological evaluation, Ginsburg (1931) demonstrated that E. minutus and E. lyricus are sufficiently different to be considered as distinct species, but Brittan (1966) synonymized them on the basis 


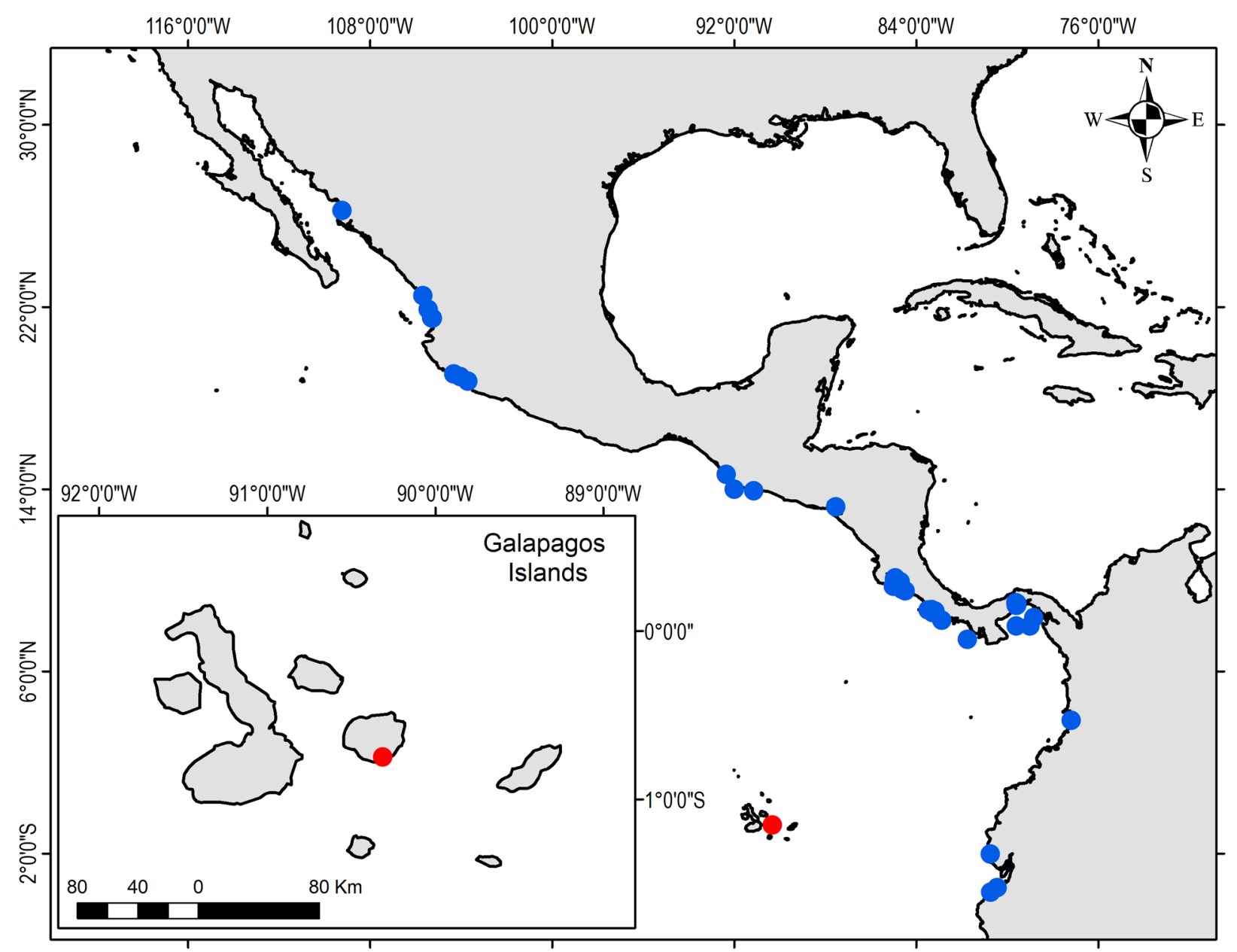

Figure 1. Records of Evorthodus minutus (blue dots) along Tropical Eastern Pacific, and newrecord (red dot) in Academy Bay, Santa Cruz Island, Galapagos.

of coloration of the body. Nevertheless, Tornabene et al. (2015) supported the differences observed by Ginsburg (1931) and estimated the divergence between of E. lyricus and E. minutus at $2.8 \mathrm{Ma}$, which coincides with the formation, during the middle- to late-Pliocene, of what is now the Isthmus of Panama (Thacker 2017). In both species, pelagic larval duration and other ontogenetic features are unknown (Borges et al. 2011); additionally, while E. lyricus has been widely studied in the Atlantic and Caribbean, E. minutus has been scarcely mentioned. Here, we provide a new record of $E$. minutus collected at the Santa Cruz Island, Galapagos Archipelago. Our record is $1,075 \mathrm{~km}$ from the closest record on mainland Ecuador. It represents the first record of this brackishwater species from an oceanic island.

\section{Methods}

During an extensive revision of gobies from the TEP hosted in the Ichthyological Collection of the California Academy of Sciences (CAS), we found a single specimen of Evorthodus minutus in a jar mixed with Bathygobius lineatus collected from tidepools of Santa Cruz Island, Galapagos Archipelago (Fig. 1) during the Templeton Crocker Expedition in 1932.
The identification of the specimen was corroborated using the original description, along with the identification keys of Robertson and Allen (2015) and Van Tassel (2012). We obtained morphometric measurements with a digital caliper with $0.1 \mathrm{~mm}$ of precision. A stereomicroscope was used for the determination of the meristic characters. Morphometric characters were expressed as percentages of the standard length (SL). Morphometric methods follow Sadeghi et al. (2017). Meristic abbreviations are as follows: D1 = first dorsal fin rays, D2 = second dorsal fin rays, $\mathrm{V}=$ ventral fin rays, $\mathrm{A}=$ anal fin rays, and $\mathrm{P}=$ pectoral fin rays. The specimen was recatalogued and is part of the Ichthyological Collection of the California Academy of Sciences .

\section{Results}

New record. Ecuador: Galapagos Archipelago: [SE shore of] Santa Cruz Island: long tidepools of Academy Bay (ca “-00.754120,$-090.286766^{\circ}$ "), collected by H. Clark \& F. Taiga (field number TCE 4-V-32; Templeton Crocker Expedition), 4 May 1932 (1 specimen, standard length: 19.93mm, female (Fig. 2); CAS 244480).

Identification. $\mathrm{D} 1=\mathrm{VI}, \mathrm{D} 2=\mathrm{I}, 10, \mathrm{~A}=\mathrm{I}, 11, \mathrm{P}=14$. Morphometric data are provided in Table 1. Body elon- 


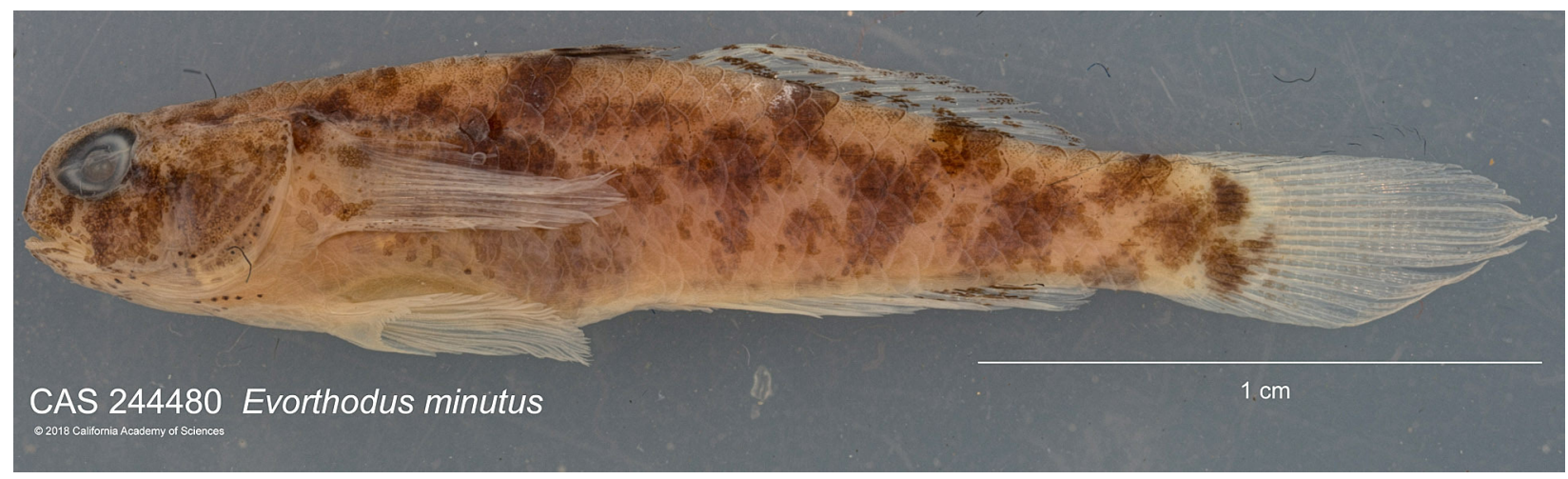

Figure 2. Evorthodus minutus collected in May 1932 from tidepools of Academia Bay, Santa Cruz Island, Galapagos (photograph: J. Fong).

Table 1. Morphometric characters of Evorthodus minutus, CAS 244480. All values except for total length (TL) and SL are proportions.

\begin{tabular}{ll}
\hline Morphometric measurements & Proportion \\
\hline Total length (TL, mm) & 26.88 \\
Standard length (SL, mm) & 19.93 \\
Standard length (SL/TL) & 0.74 \\
Head length (HL/SL) & 0.24 \\
Body depth (BD/SL) & 0.21 \\
Snout length (SN/SL) & 0.26 \\
Eye diameter (ED/SL) & 0.064 \\
Predorsal distance length (PD/SL) & 0.47 \\
Pectoral length (PL/SL) & 0.28 \\
Pelvic lengthht (PeL/SL) & 0.23 \\
Caudal peduncle length (CP/SL) & 0.13 \\
Caudal fin length (CF/SL) & 0.28 \\
Anal fin base length (AFL/SL) & 0.30 \\
First dorsal fin length (FDL/SL) & 0.11 \\
Second dorsal fin length (SDL/SL) & 0.30 \\
\hline
\end{tabular}

gated, brown, with darker brown spots forming indistinct bars on the body: the first bar on the base of first dorsal fin and covering the first spines, the second bar on the posterior half of the second dorsal, and the third on the last rays of the second dorsal. Base of caudal fin with 2 spots: upper spot slightly darker and smaller than lower spot. Upper base of pectoral fin with another spot; lower base with several small brown spots. Head short, compressed; snout steeply rounded in profile. Eyes large, with 2 pores between them; 1 pore behind eye and 1 on preopercle. Head and nape with large scales. Head, cheek, preopercle and operculum with small brown dark blotches. Jaw slightly inclined. Union of jaws almost reaching iris. Edge of lower lip with a series of spots. Throat with a series of spots. Pelvic fin almost reaches anus. Pectoral, pelvic and caudal transparent; anal fin with brown spots on last 4 rays. First dorsal with a dark bar, second dorsal with at least 2 transverse brown lines. Tongue truncated; teeth with flattened, forked tips, in a single row on side of each jaw.

The specimen corresponds to the original description of E. minutus in the coloration on the body, markings (including the presence of 2 characteristic brown spots on the base of the caudal fin), size, body form and other structures such as teeth, tongue and pores on the head.

Evorthodus minutus was found in a jar mixed with Bathygobius lineatus (Jenyns, 1841), an endemic species from the Galapagos Archipelago. Bathygobius lineatus has a total length of $12 \mathrm{~cm}$, while E. minutus has a total length to a maximum of $3.6 \mathrm{~cm}$ (Robertson and Allen 2015). However, juveniles of $B$. lineatus tend to have small blotches on the body and caudal peduncle and could be confused with other cryptobenthic tidepools species, even with E. minutus. Probably, for this reason, $E$. minutus was not recognized from $B$. lineatus. However, $E$. minutus cannot be confused with $B$. lineatus because there are a large number of distinctive characteristics such as the form of the head (short and rounded in $E$. minutus), the first 5 superior rays (separate and bifurcate in $B$. lineatus), and the presence of 3 blotches behind the eye (in B. lineatus).

\section{Discussion}

Evorthodus minutus is a brackish-water shallow-dwelling species which inhabits intertidal zones to about $5 \mathrm{~m}$ on mud substrate of mangrove ecosystems (Robertson and Allen 2015); and sometimes, it can enter freshwater (Van Tassell and Findley 2010). This species is distributed in the TEP from Sinaloa, Mexico to southern Gulf of Guayaquil, Ecuador, and is usually found in mangrove ecosystems along the Central American coast. This specimen represents the first record of E. minutus from the Galapagos Archipelago and is $1,075 \mathrm{~km}$ from the nearest previous mainland Ecuador occurrence (Santa Elena, northern Guayaquil).

The record from the Galapagos, $1,075 \mathrm{~km}$ from the nearest previously known record on mainland Ecuador, raises the question about the connectivity pathways in the equatorial eastern Pacific and in particular from mainland Central America to oceanic islands such as Cocos, Malpelo, Gorgona and Galapagos. Based on genetic and biophysical modelling approaches, Lessios and Baums (2017) and Romero-Torres et al. (2018) showed that the most likely dispersal routes in the equatorial eastern Pacific is northward and southward along Central America by following the Costa Rica Coastal Current and the branch that feeds the Panama Gyre, the Panama Current, 
and later the South Equatorial Current. As such, records of E. minutus north and south of $04^{\circ} \mathrm{N}$ on the Central American mainland might be explained by the dispersal of individuals carried the North Equatorial Counter Current that splits into 2 branches off the coast of Costa Rica. Based on a biophysical model, Lequeux et al. (2018) suggested that the islands of Malpelo and Gorgona serve as "stepping stones" between the mainland and offshore islands, such as the Galapagos. This suggests that the record of E. minutus from Santa Cruz Island might be the result of quasi-unidirectional larval flow from the continent to oceanic islands in the equatorial eastern Pacific.

Colonization by ballast water (Academy Bay is an important port) might also be responsible, such as for other vagrant marine species (sensu MacIsaac et al. 2016). However, the most likely hypothesis is by natural dispersal mechanisms (Sandel et al. 2011). Pinheiro et al. (2017) showed that "weak colonizers" are commonly composed by small species and tend to colonize oceanic islands using the seamounts as "stepping stones", which leads to vicariance, as similarly observed in the genus Tigrigobius in the TEP (Hoese and Reader 2001). Pinheiro et al. (2017) suggested that persistence of new populations of weak dispersers depends on gene flow or, otherwise, these populations become extinct in a short time. This could be a reason for the apparent absence of records of the species in the Galapagos now. Nevertheless, the Santa Cruz record of E. minutus presents a new addition to the marine fish species from the Galapagos Archipelago and is the first record for a brackish-water species from an oceanic island in the TEP.

\section{Acknowledgements}

OVM expresses his gratitude to the Lakeside Foundation for the generous support during the visit to the California Academy of Science, San Francisco. We thank Jon Fong for taking the photographs. We thank the California Academy of Sciences for permission to use the photograph in Figure 2. OVM is supported with a $\mathrm{PhD}$ fellowship from CONACYT (\#275299). This manuscript was enriched and improved by the helpful comments from Hudson Tercio Pinheiro, Robert Forsyth, and by 2 reviewers, Remy Gatins and Arturo Angulo.

\section{Authors' Contributions}

OVM examined and identified the specimen. All authors prepared, reviewed, finalized, and approved the manuscript.

\section{References}

Borges R, Faria C, Gil F, Goncalves EJ (2011) Early development of gobies. In: Patzner RA, Van Tassell JL, Kovacic M, Kapoor BG (Eds) The Biology of Gobies. Boca Raton: CRC Press, 403-464.

Brittan MR (1966) A small collection of fishes from the west coast of Costa Rica. Ichthyologica 37: 121-134.

Bussing WA (1990) New species of gobiid fishes of the genera Lythrypnus, Elacatinus and Chriolepis from the eastern tropical Pacific.
Revista de Biologia Tropical 38 (1): 99-118.

Bussing WA (1997) Chriolepis atrimelum (Gobiidae) a new species of gobiid fish from Isla del Coco, Costa Rica. Revista de Biología Tropical 45 (4): 1547-1552.

Cheffe MM, Lanés LEK, Volcan MV, Burns MD de M (2010) Pisces, Perciformes, Gobiidae, Evorthodus lyricus (Girard, 1858): new record from Patos-Mirim lagoon system, state of Rio Grande do Sul, southern Brazil. Check List 6 (4): 676-678. https://doi. org/10.15560/6.4.676

Dawson CE (1967) Notes on the species of the goby genus Evorthodus. Copeia 1967(4): 855-857.

Fricke R, Eschmeyer WN, van der Laan R (2018) Catalog of fishes: genera, species, references. California Academy of Sciences, San Francisco, California. http://researcharchive.calacademy.org/research/ ichthyology/catalog/fishcatmain.asp. Accessed on: 2018-11-28.

Gill TN (1859) Description of a type of gobioids intermediate between Solinae and Tridentigerinae. Proceedings of the Academy of Natural Sciences of Philadelphia 11: 195-196.

Ginsburg I (1931) Juvenile and sex characters of Evorthodus lyricus (fam. Gobiidae). Bulletin of the (U.S.) Bureau of Fisheries 47: $117-124$.

Girard CF (1858) Notes upon various new genera and new species of fishes, in the museum of the Smithsonian Institution, and collected in connection with the United States and Mexican boundary survey: Major William Emory, Commissioner. Proceedings of the Academy of Natural Sciences of Philadelphia 10: 167-171.

Hoese DF, Reader S (2001) A preliminary review of the eastern Pacific species of Elacatinus (Perciformes: Gobiidae). Revista de Biología Tropical 49: 157-167.

Lequeux BD, Ahumada-Sempoal MA, López-Pérez A, Reyes-Hernández C (2018) Coral connectivity between equatorial eastern Pacific marine protected areas: A biophysical modeling approach. PloS ONE 13 (8): e0202995. https://doi.org/10.1371/journal.pone.0202995

Lessios HA, Baums IB (2017) Gene Flow in Coral Reef Organisms of the Tropical Eastern Pacific. In: Glynn P, Manzello D, Enochs I (Eds) Coral Reefs of the Eastern Tropical Pacific. Coral Reefs of the World, vol 8. Springer, Dordrecht, 477-499. https://doi. org/10.1007/978-94-017-7499-4_16

MacIsaac HJ, De Roy EM, Leung B, Grgicak-Mannion A, Ruiz GM (2016) Possible Ballast Water Transfer of Lionfish to the Eastern Pacific Ocean. Plos ONE 11 (11): e0165584. https://doi. org/10.1371/journal.pone.0165584

Meek SE, Hildebrand SF (1928) The marine fishes of Panama. Part III. Field Museum of Natural History, Publications, Zoölogical Series 15 (249): 709-1045, Pls. 72-102.

Pezold F (2004) Phylogenetic analysis of the genus Gobionellus (Teleostei: Gobiidae). Copeia 2004 (2): 260-280. https://doi. org/10.1643/CI-02-218R3

Pinheiro HT, Bernardi G, Simon T, Joyeux J-C, Macieira RM, Gasparini JL, Rocha C, Rocha LA (2017) Island biogeography of marine organisms. Nature 549 (7670): 82-85. http://doi.org/10.1038/ nature 23680

Robertson DR, Allen GR (2015) Peces costeros del Pacífico Oriental Tropical: sistema de información en línea. Version 2.0. Instituto Smithsonian de Investigaciones tropicales, Balboa, República de Panamá. http://biogeodb.stri.si.edu/sftep/es/pages. Accessed on: 2018-11-28.

Romero-Torres M, Treml EA, Acosta A, Paz-García DA (2018) The Eastern Tropical Pacific coral population connectivity and the role of the Eastern Pacific Barrier. Scientific Reports 8 (1): 9354. https:// doi.org/10.1038/s41598-018-27644-2

Sadeghi R, Esmaeili HR, Fricke R, Larson HK (2017) New geographical record and morphological features of the Indo-Pacific tropical sand goby, Favonigobius reichei (Bleeker, 1854) from Iranian coast of the Makran Sea (Teleostei: Gobiidae). Check List 13 (5): 641-645. https://doi.org/10.15560/13.5.641

Sandel B, Arge L, Dalsgaard B, Davies RG, Gaston KJ, Sutherland WJ, Svenning J-C (2011) The influence of Late Quaternary cli- 
mate-change velocity on species endemism. Science 334 (6056): 660-664. https://doi.org/10.1126/science.1210173

Thacker CE (2017) Patterns of divergence in fish species separated by the Isthmus of Panama. BMC Evolutionary Biology 17: 111. https://doi.org/10.1186/s12862-017-0957-4

Tornabene L, Valdez S, Erdmann M, Pezold F (2015) Support for a "Center of Origin" in the Coral Triangle: cryptic diversity, recent speciation, and local endemism in a diverse lineage of reef fishes (Gobiidae: Eviota). Molecular Phylogenetics and Evolution 82: 200-210. https://doi.org/10.1016/j.ympev.2014.09.012

Valencia-Méndez O, Rodríguez-Zaragoza FA, Calderon-Aguilera LE,
Domínguez-Domínguez O, López-Pérez A (2018) Gamma-diversity partitioning of gobiid fishes (Teleostei: Gobiidae) ensemble along of Eastern Tropical Pacific: biological inventory, latitudinal variation and species turnover. PLoS ONE 13 (8): e0202863. https://doi.org/10.1371/journal.pone.0202863

Van Tassel J (2012) Key to Species_-Eastern Pacific. Gobioid Research Institute. http://www.gobiidae.com/species_pages/evothodus_minutus. htm. Accessed on: 2018-08-28.

Van Tassell J, Findley L (2010) Evorthodus minutus. The IUCN Red List of Threatened Species 2010: e.T183413A8109283. https://doi. org/10.2305/iucn.uk.2010-3.rlts.t183413a8109283.en 